\title{
An Assessment of Jeddah's Hydraulic Protection and Management Systems of Flood
}

\author{
Atef Belhaj Ali' ${ }^{1}$, Faouzi Ameur ${ }^{2}$ \\ ${ }^{1}$ Department of Geography, Faculty of Arts \& Humanities, King Abdulaziz University, Jeddah, KSA \\ ${ }^{2}$ Department of Geomatics, Faculty of Environmental Design, King Abdulaziz University, Jeddah, KSA \\ Email: amalhabeb@kau.edu.sa,faouzi@netcourrier.com
}

How to cite this paper: Belhaj Ali, A. and Ameur, F. (2018) An Assessment of Jeddah's Hydraulic Protection and Management Systems of Flood. Open Access Library Journal, 5: e4288.

https://doi.org/10.4236/oalib.1104288

Received: December 25, 2017

Accepted: February 25, 2018

Published: February 28, 2018

Copyright $\odot 2018$ by authors and Open Access Library Inc.

This work is licensed under the Creative Commons Attribution International License (CC BY 4.0).

http://creativecommons.org/licenses/by/4.0/

\section{cc (7) Open Access}

\begin{abstract}
Located in the South-west of Saudi Arabia, Jeddah is more than a harbour. It is Saudi Arabia's biggest Red Sea city and second only to Riyadh the capital. During summer, this metropolis becomes a political capital and a tourist resort for foreigners and Saudis alike. The city of Jeddah was affected by serious and unexpected floods; two great ones took place in 2009, and in 2011. The human and material toll was considerable, since these floods caused the death of hundreds of people, damaged thousands of buildings built on basins' slopes, which, however, had the necessary building permits. To cope with these natural disasters, several urban hydraulic measures were undertaken: like building dams and canals to collect surface waters. These urban measures aimed at the protection of inhabitants and belongings against the risks of floods as well as the interception and the drainage of water streams. Although these protection measures are important, expensive, and effective, they are no longer enough or effective to cope with the evolution of the natural disasters that the city of Jeddah is constantly exposed to. These protective hydraulic measures have not made it possible to reach risk zero situations. Damages and risks are transferred to other zones. After reviewing the description of the city of Jeddah, its urban sprawl and thus the damage suffered following the floods of 2009 and 2011, we draw up an inventory of the infrastructures set up in order to protect the city and minimize the damage during future floods. We will also expose a criticism of these infrastructures through the previous scientific works and through the observation during the rains of 2015 and 2016.
\end{abstract}

\section{Subject Areas}

Environmental Sciences

\section{Keywords}

Jeddah, Flood, Hydraulic Protection 


\section{Introduction}

As shown in Figure 1, Jeddah is a Saudi Arabia city located in the middle of the eastern coast of the red sea. It is also the biggest port city of the Kingdom and its second-largest city after the capital city, Riyadh. Jeddah has about 4,000,000 inhabitants and this population represents $14 \%$ of the population of Saudi Arabia. The city has economic assets due to its being a transit city to Islam holly cites like Mecca and Medina. Jeddah is indeed the principal gateway to Mecca, Islam's holiest city, that able-bodied Muslims are required to visit at least once in their lifetime. It is also a gateway to Medina, the second holiest place in Islam. Despite being characterized by an arid climate with a hot temperature-usually approaching 50 degrees Celsius or more-Jeddah also has low and unpredictable precipitation [1]. Precipitation is often inferior to evaporation. The city receives less than $70 \mathrm{~mm}$ of average annual precipitation but it often witnesses sudden floods like, for instance, the two big floods in 2009, 2011 where human and economic losses were extremely important.

These exceptional events, led local and national authorities to focus on Jeddah's floods in order to find suitable solutions like hydraulic infrastructure protections [2] [3].

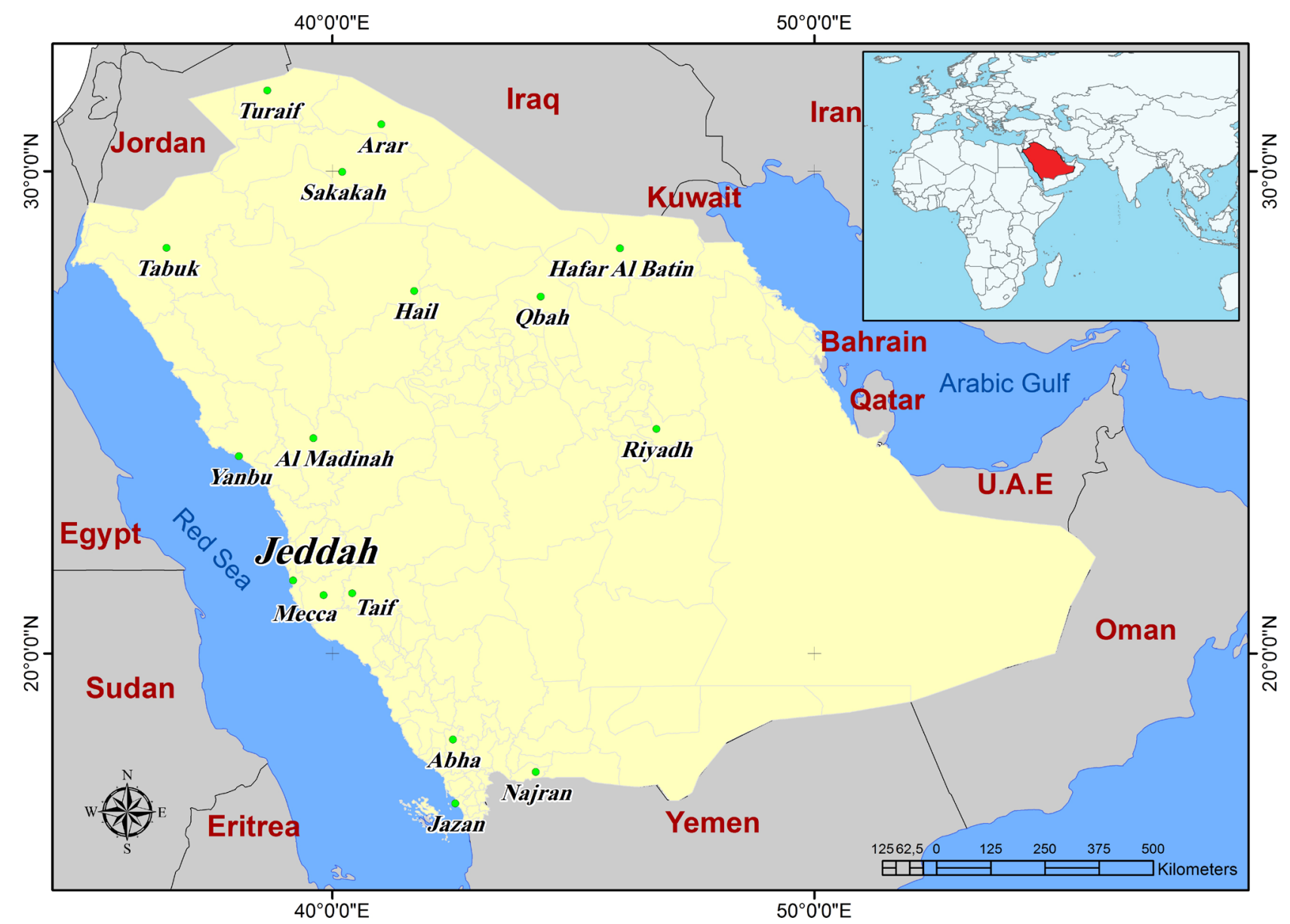

Figure 1. Geographical location of Jeddah (data provided by King Abdullah city for atomic and renewable energy geoportal). 


\section{Flood Problem of the Study Area}

\subsection{Rain Characteristics and Rain Fall Patterns in Saudi Arabia}

Saudi Arabia is situated in a tropical and sub-tropical zone with latitudes $16^{\circ} \mathrm{N}$ $32^{\circ} \mathrm{N}$ and longitudes $35^{\circ} \mathrm{E}-58^{\circ} \mathrm{E}$. It has a large area of 2 million square kilometres which is characterized by a hot climate and scarce rainfall [4]. The dry air masses developing in North Africa and in South Asia reach Saudi Arabia without appropriate moisture. Most regions in Saudi Arabia receive small amount of rainfall averaging less than $100 \mathrm{~mm}$ per year [5]. Generally, rainfall is unpredictable, irregular but can be very intensive during local storms. The amounts of rain decrease and vary from North to South and from West to East [5]. The relatively high zone of rainfall is in the South-Western part of the Kingdom-a part which receives more than $200 \mathrm{~mm}$ per year [6]. There is a marked decrease of rainfall in the eastern regions which are extremely arid. Most of the rainfall occurs in the period from November to May, while summer months have virtually no rainfall at all except in the South-Western region.

\subsubsection{Rain Fall Characteristics}

Heavy rainfall can be defined as the precipitation which exceeds $25 \mathrm{~mm}$ per hour [7]. In Jeddah, the heavy rainfall is caused by the cold fronts caused by northerly winds moving from the eastern Mediterranean Sea towards the Arabian Gulf [8]. It may result in the following:

- Floods which can endanger human life, destroy buildings and infrastructure, spoil crops and livestock [9].

- Landslides which can imperil lives and interfere with transport and communication systems [9].

Heavy rainfall and flash floods create havoc and disaster all over the world. Whether it is in Asia, in Europe, in East or West, this form of severe weather has caused heavy losses of lives and property. Those who suffer the most during natural calamities are ordinary civilians. Moreover the state usually faces potentially high economic losses when such natural calamities happen. Also, there are always high risks of epidemics which increase the' suffering of civilians [7].

\subsubsection{Pluviometric Mode in Jeddah}

Jeddah has a pluviometric mode which is characterized by a great inter-annual variability. This mode alternates wet and dry years [10] (like in 1996 which recorded $284 \mathrm{~mm}$ and 1986 where no drop of rain was recorded according to the treated data) see Figure 2. Precipitations occur in winter (they start in October and finish in April). The rainy season is typical of the climate of temperate zones and Mediterranean characteristics [11] and has nothing in common with the mode of monsoon which is generally active during July and September. November often records heavy rains. Having said that, the protection Civil Services must be more vigilant to face flood periods. The analysis of daily precipitations is interesting since its shows that daily precipitations during 2009 reached about $70 \mathrm{~mm}$ causing "Flash floods" in 24 hours-the most important flash flood since 


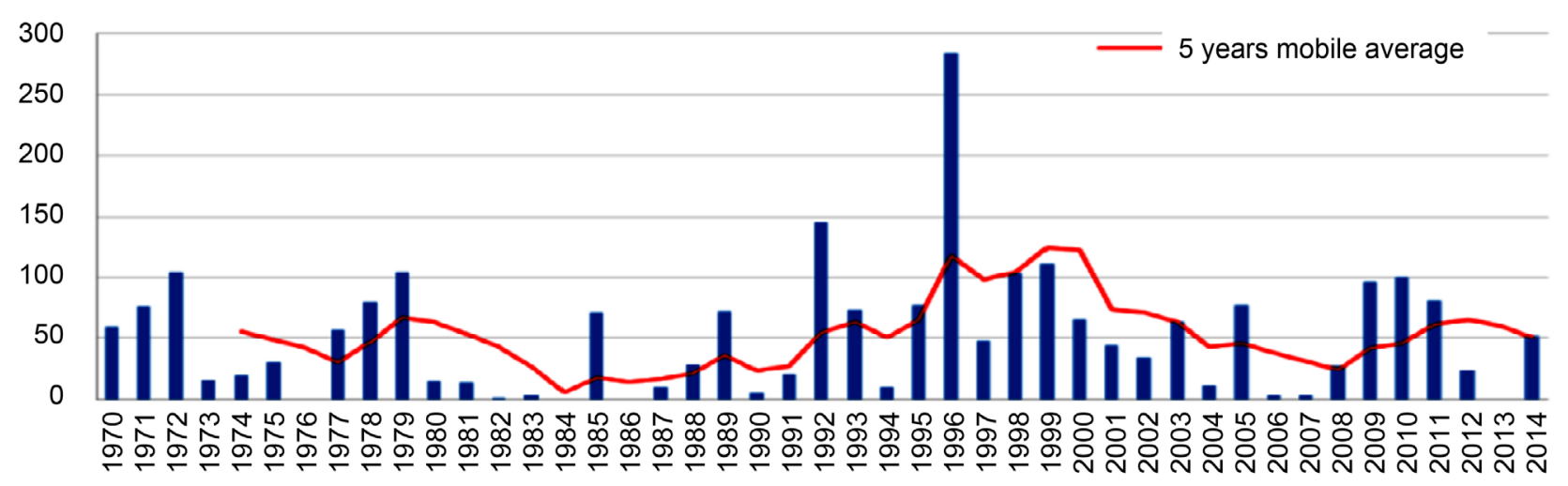

Figure 2. Annual pluviometry between 1970 and 2014 at Jeddah station.

1979. The urban growth that Jeddah underwent over the more recent years, explains the gravity and the extent of the recorded catastrophes. The 1970s did not record major floods and this despite the heavy precipitations recorded in 1972, 1973, 1978 and 1979 [11]. One plausible cause of the absence of floods during the 1970s can be attributed to the absence of the urban development in risk zones like riverbeds and wadis. One can mention that 1996 knew exceptional annual precipitation, but damages occurred because rain fall stretched over several days [12].

\subsection{Urban Growth}

\subsubsection{Increase of Urban Population in Saudi Arabia}

The United Nations' department of economic and social affairs estimated that the population of Saudi Arabia increased from 3,121,000 in 1950 to 31,540,000 in 2015 [13]. It was close to 5,772,000 in 1970. It reached 16,139,000 in 1990 and $27,448,000$ in 2010. By 2030 the Kingdom's populations is estimated to reach around 39.1 million. However, as stated by the Enesco, since the establishment of the Kingdom of Saudi Arabia in 1932 and until 1960, the life style of most of the population was nomadic or semi-nomadic [14]. More than half of the population derives its resources from pastoral activities. Due to the Kingdom's urban development more than $95 \%$ of the population is now sedentary. Big urban centers like Riyadh, Jeddah, Medina, Makkah and Dammam have experienced enormous growth starting from 1973 [15]. Today, the process of urban growth in Saudi Arabia is one of the fastest in the world [16]. Around $78.8 \%$ of the Saudi population lives in cities nowadays.

\subsubsection{Urban Sprawl in Jeddah}

Jeddah was confined to the old city known as "Elbaled" (Figure 3). The demolition of the walls of the ancient city in 1947 ushered in Jeddah's expansion process. From 1973 till the present, the city's northern and southwestern expansion continued to grow [11]. It should be mentioned at this level that Jeddah's expansion was mainly to the North and occasionally to other directions.

Numerous studies related to the floods of 2009 and 2011 show that: 


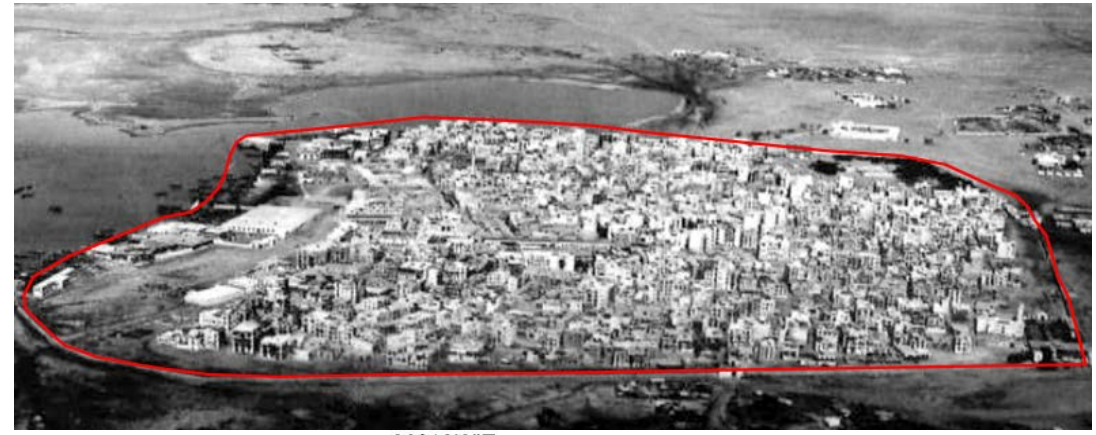

$39^{\circ} 10^{\prime} 0^{\prime \prime} \mathrm{E}$

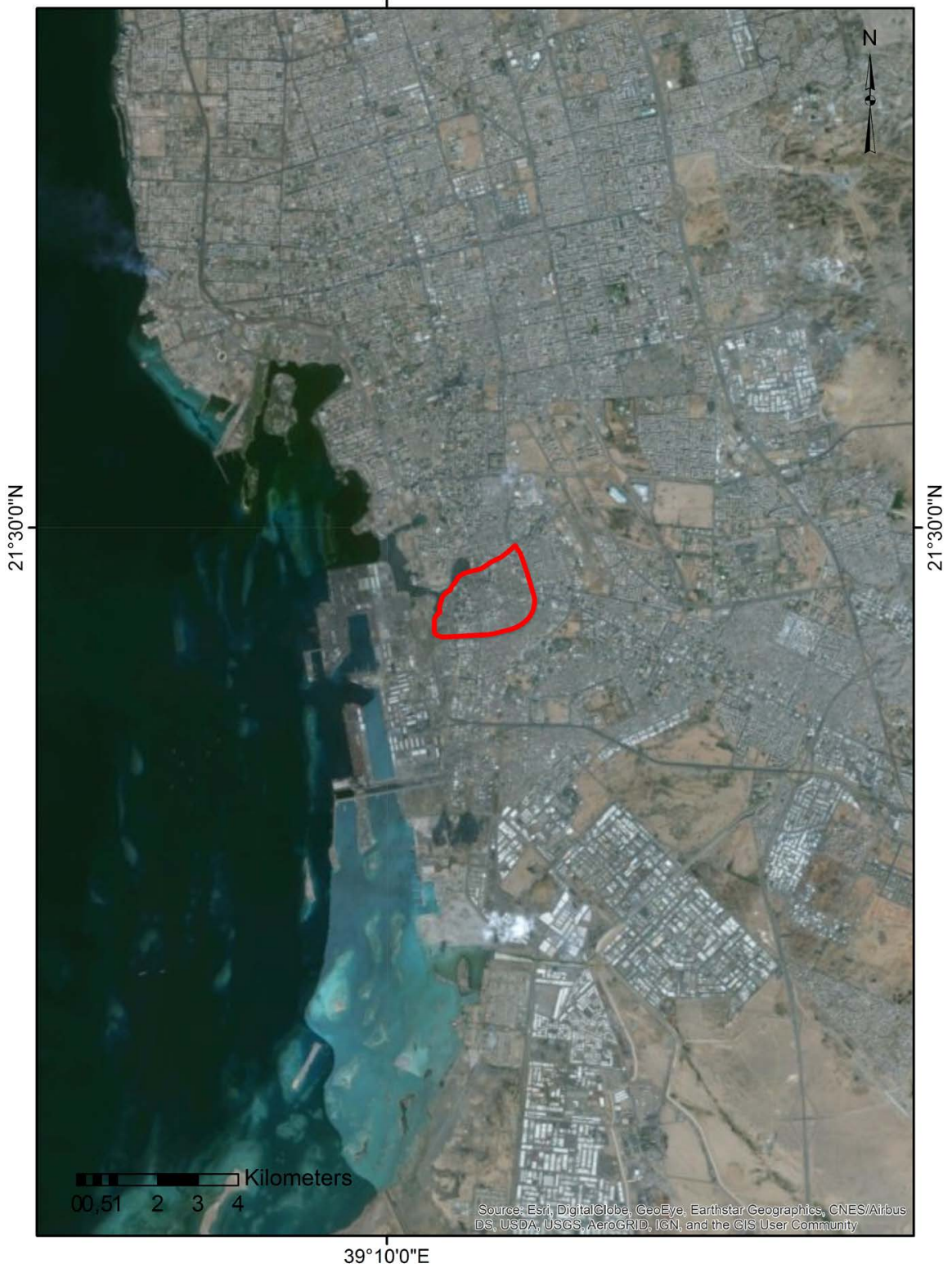

Figure 3. Jeddah prior to the demolition of the walls.

- Urban flooding is becoming more dangerous and more costly to manage. This is due to the sheer size of the population and to the huge geographical growth of the city [17]. 
- The addition of more roads, houses, and commercial and industrial buildings transformed Jeddah and affected its hydrologic cycle.

- Available grounds used to soak and absorb flood water are used for roads and roads' pavements. This increased the risks of flooding and damaged the water quality of the city's streams.

As a consequence, when infiltration is decreased sufficiently enough, groundwater levels may decline, affecting stream flows during dry weather periods. When wise choices are made during the development process, the above negative impacts can be minimized and future water supplies protected (Figure $4)$.



Figure 4. Jeddah's Urban sprawl. 


\subsection{Risk Definition}

Flooding can be caused by a number of processes, but the dominant cause is often precipitation. Floods are a natural process often aggravated by anthropogenic activities. Floods occur at irregular intervals and vary in power, the extent of the damaged area, and duration.

Every flood is different. They can occur suddenly, or may take days or even months to disappear and unload. They occur at often irregular intervals.

However, the notion of risk cannot be defined without defining the concept of vulnerability and exposure. The concept of vulnerability in this definition does not make it possible to distinguish between simple physical exposure to risks on the one hand and the sensitivity of persons or things to risks on the other hand. We adopt the following definition of a risk:

"Risk is the likelihood of a loss that depends on three elements: hazards, vulnerability and exposure." If one of these three elements increases or decreases, the risk increases or decreases respectively [18]. Although exposure refers in the context of flooding only to the question of whether people or property are physically exposed to flood waters or not, vulnerability can be defined as "conditions determined by factors or physical, social, economic and environmental processes that increase the sensitivity of a community to the impact of risks." Thus, risk can be considered as a combination of these 3 factors: hazard, vulnerability and exposure [19].

\subsection{The Consequences of Flood}

In the past, floods used to be limited to rural areas, but it has now become pervasive in urban ones as well. With their high population densities and concentration of diverse economic activities, cities around the world, particularly in developing countries, face tremendous challenges in dealing with flood-related risks. Due to the increase of impermeable surfaces such as roofs, parking lots, pavements, flood rises very quickly and exceeds the capacity of storm water facilities to drain rapidly. The results were severe damages to urban infrastructure etc.

The city of Jeddah was affected by two major flash floods during November 2009 and January 2011. More than 110 people were killed [20] [21]. Buildings and many other properties were destroyed and hundreds of cars were swept to the sea. Hundreds of families were left homeless and forced to move in with relatives living in other cities in Saudi Arabia. Huge traffic jams were reported in the city's major highways by the Jeddah Traffic Department. Such traffic jams lasted hours throughout that week [22] [23]. Hundreds of residents experienced power failures as reported by the Saudi Electricity Company. Actually, more than 5000 people were without electricity. Some buildings in the city caught fire-Hera Mall for instance-and reportedly others cracked and as a result collapsed to the grounds. Business losses were estimated at about one billion dollars.

In November 2009, the search for missing bodies in Jeddah City took longer 
than expected since the Civil Defense authorities did not use modern technologies to detect the missing bodies [24]. This delayed the declaration of the recovery stage in addition to the lack of cranes and other equipments. These shortcomings could be due to lack of emergency management body to take over the task of knowing the needs of the city of Jeddah to deal with future disasters (Figure 5 and Figure 6).

\section{Flood Control and Management}

In November 2009 heavy quantities of rain in the city of Jeddah caused floods and drowned several neighborhoods. More than a hundred citizens lost their lives. This was one of the worst disasters that Jeddah knew over the last 27 years. Other tragedies were witnessed during two multiples rains in 2009. The floods of 2011 caused the collapse of the dam of Om-Elkhir and the sinking of neighborhoods in the east of the city [15].

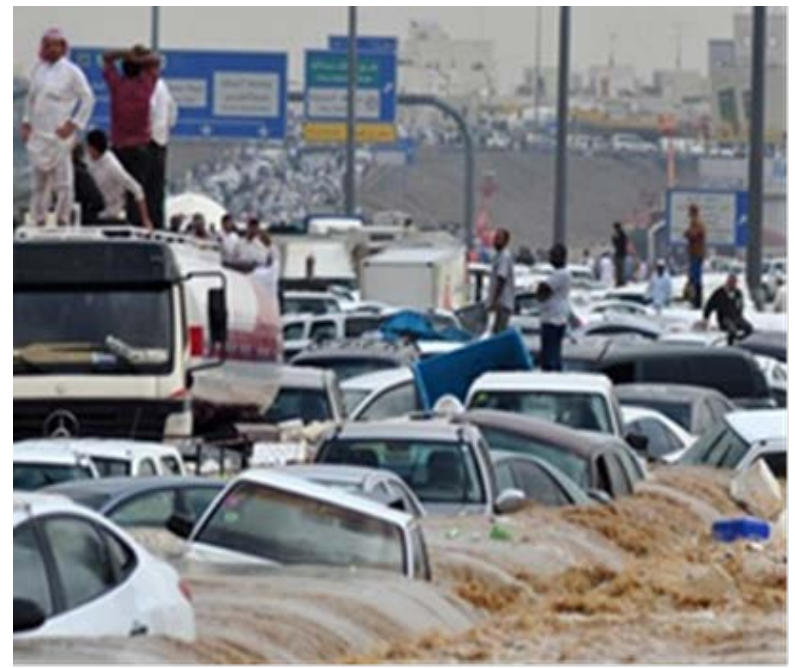

Figure 5. Jeddah's flood in 2009.



Figure 6. Jeddah's flood in 2011. 


\subsection{The Urgent Solutions}

Construction of Om Elkhir's Dam (Figure 7).

- Consolidation works in the Dam of the Samer (Figure 8).

- Creation of 12 basin places to gather rain water near tunnels and intersections.

\subsection{The Permanent Solutions to Protect the Developmental Range for City Jeddah: Flood Risks}

\subsubsection{Construction of Dams}

Constructed on of five dams:

- Dam of WadiGhia

- Dam of Wadi Om-Habliein

- Dam of WadiDaguig

- Dam of WadiBriman

- Dam of WadiGalil

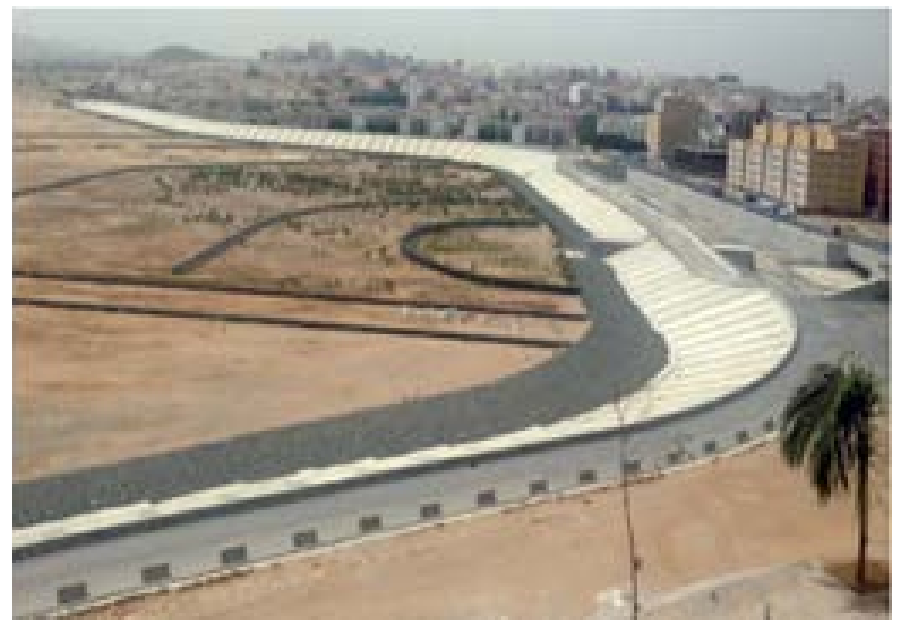

Figure 7. Dam of Om Elkhir.

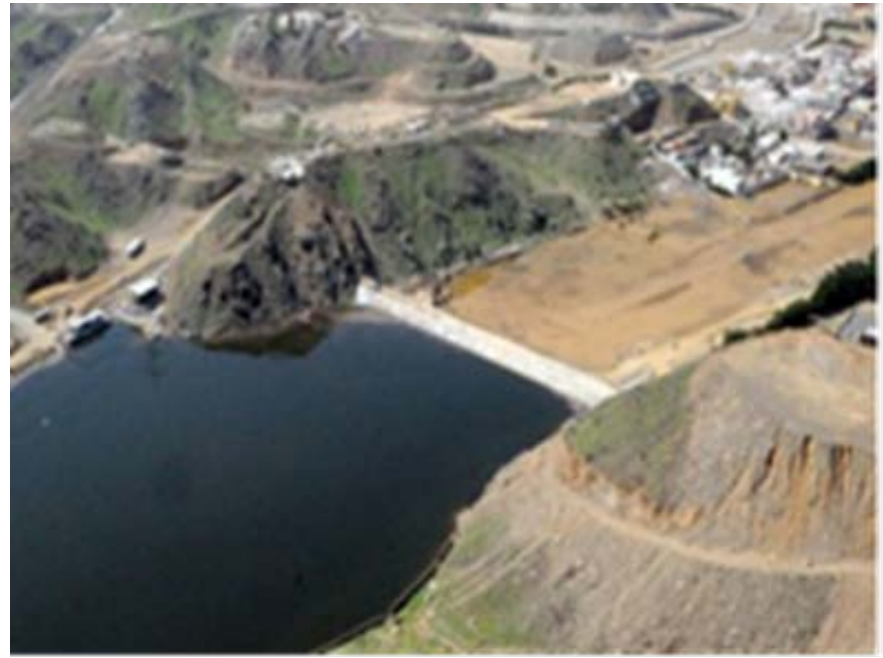

Figure 8. Dam of Samer (constructed after 2009). 
The primary purpose of these dams is to reduce the flood flow through the sewer sub-channels with a total length of approximately 20 kilometers of drainage pipes to discharge water into the sea gradually and safely within 15 days. Reducing thus the risk of flooding in the city of Jeddah

\subsubsection{Construction of Retention Basins}

Retention basins are management projects intended to intercept the largest possible quantities of rain water in artificial basins. Processes such as mechanical settling of suspended sediments and biological nutrients contribute to improved water quality. The best locations are generally low areas suited for natural drainage ways. In Jeddah the retention basins were constructed in Ennassim District near King Abdullah Road after the flood of 2009 (Figure 9).



Figure 9. Retention basins in ennassim district (Jeddah). 


\subsubsection{Create Rain Water Drainage Channels (Figure 10)}

\section{- Eastern Stream Channel}

The eastern waterway gathers most of floodwaters recuperated east of King Abdul Aziz Airport where 4 dams have been built (WadiGhia, Wadi Om-Habliein, WadiDaguig and WadiBriman). The Length of the water-way is about $24 \mathrm{~km} \cdot \mathrm{s}$. It directs flood water from WadiBriman near Mecca Road to Suliman Gulf.

\section{- Airport Canal}

The construction of the Airport Canal-about $34 \mathrm{~km}$-is located in the Northeastern and Northwestern part of Jeddah. This canal is one of the mega projects in Jeddah.

- North Stream Channel

The Northern waterway directs rainwater from the dams of Samer and Om-Elkhir by way of Prince Mohamed Bin Abdel Aziz Road. It is about $20 \mathrm{~km}$ long.

- South Stream Channel

The South stream channel extending from WadiGhia to King Abdel Aziz University, directs rainwater to the Red Sea. It is about $24 \mathrm{~km}$ long.

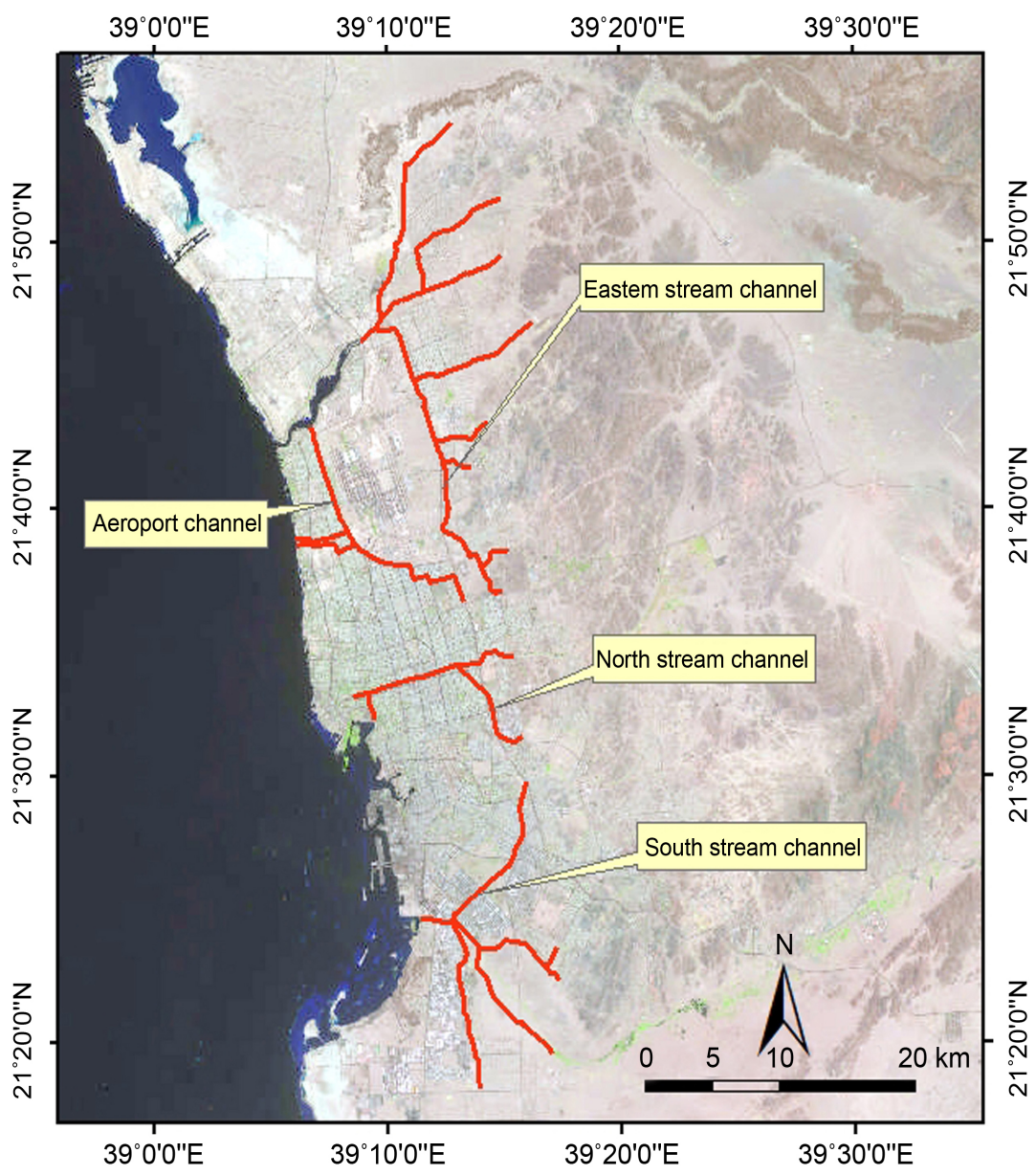

Figure 10. Showing rainwater drainage channels. 


\subsection{Permanent Solutions to Protect Urban Sprawl of East of Jeddah}

- The construction of open canal $(37 \mathrm{~km})$ to avoid flood risks from WadiElkhomra.

- The construction of open canal $(7.6 \mathrm{~km})$ east of Jeddah to contain the flood risks of WadiBriman and Wadi Om-Hablein.

- The construction of open canals to deflect rainwater North of King Abdel Aziz Airport in order to protect many areas from flood risks like King Abdel Aziz Sport City.

- The construction and completion of open canals $(44 \mathrm{~km})$ to prevent flood risks from WadiKaraa and WadiMreikh.

\section{Evaluation of Hydraulic Protection Systems against Floods}

Many studies try to measure flooded zones and identify the problems and causes [2] [19]. All studies agree that anthropogenic actions have the major the responsibility for the negative consequences, especially the urban expansion along the watercourses and at the outlets downstream where new settlements have been constructed.

\subsection{The High Costs}

According to [21] [22] [24], Jeddah flood protection projects cost nearly $\$ 904$ million and required:

- Working on 205 sites.

- 133,000 workers.

- 20 million hours of work.

- 2805 heavy duty machines.

- 230 thousand tons of iron-a quantity huge enough to build six copies of Tour Eiffel.

Despite the high cost of Jeddah flood protection projects,

- Some dams, namely Galil, Goss and Mathoub, may collapse at any time due to inability to manage the maximum flow of rainwater.

- The lack of coordination between the various stakeholders in the Ministry of Water and Electricity, Jeddah Prefecture, Aramco Society and the Principality of Mecca.

- The lack of maintenance.

\subsection{Partial Success and Persistence of Risks}

Jeddah flood protection projects were successful in November 2015 to carry more than 36 million cubic meters of rainwater to the sea and protect the city from a major disaster. But the rain that fell in November 2015 and December 2016 and that have not exceeded $25 \mathrm{~mm}$ just demonstrated that this success was only limited. Indeed, according to the meteorological station of the King Abdel 
Aziz University only $24.1 \mathrm{~mm}$ (November 2015) of rain was recorded. But this small quantity was enough to submerge most of the city and cause the death to two people. Several cars were transported by floods. Roads were transformed into river systems.

\subsection{Lack of Comprehensive Approach}

The objective of setting up large flood protection infrastructures (Figure 11) was essentially to protect the city from the flow of rainwater coming from the mountains without taking into consideration the phenomenon of urbanization and the urban extension of the city. Indeed, Jeddah was surrounded by an arsenal of dikes and tens of kilometers of rainwater drainage canals. But the city still remains threatened by the de facto inundation because of:



Figure 11. Hydraulic protection system. 
- The absence of a system of evacuation of water inside the city and especially the absence of the network of sanitation knowing that most of the buildings are equipped by artificial concrete pits to stock waste water. This allowed the saturation of the water table. As a result, rainwater can no longer infiltrate and turn roads into river systems.

- The hydraulic protections systems as a whole did not reduce the risks of floods in certain areas but the danger or risks were relocated in other places close to the mountains and to the riverbeds.

\section{Conclusions}

The construction of major water infrastructures to protect Jeddah from flooding required heavy investments. But in spite of these efforts, the city of Jeddah is still under serious flood threats and with every precipitation, the inhabitants of the Kingdom's second biggest city live in fear and remain haunted by the unknown. Indeed, it is imperative to take more measures to minimize the risks, in particular:

1) Develop awareness programs for the population to prevent them from flooding.

2) Review existing planning regulations and formally prohibit constructions in watercourses particularly at the level of their minor and major beds, to minimize the exposure factor and therefore reduce the risks.

3) Conduct more hydrological simulation studies, especially those concerning urban hydraulics, especially since the sewerage network of the city of Jeddah is not very developed.

\section{References}

[1] Qari, M.H.T. (2009) Geomorphology of Jeddah Governorate, with Emphasis on Drainage Systems, JKAU. Earth Science, 20, 93-116.

[2] Al Saud, M. (2010) Assessment of Flood Hazard of Jeddah Area 2009, Saudi Arabia. Journal of Water Resource and Protection, 2, 839-847. https://doi.org/10.4236/jwarp.2010.29099

[3] Youssef, A.M., Pradhan, B., Sefry, S.A. and Abu Abdullah, M.M. (2015) Use of Geological and Geomorphological Parameters in Potential Suitability Assessment for Urban Planning Development at Wadi Al-Asla Basin, Jeddah, Kingdom of Saudi Arabia. Arabian Journal of Geosciences, 8, 5617-5630. https://doi.org/10.1007/s12517-014-1663-9

[4] Meigs, P. (1951) La Répartition mondiale des zones climatiques arides et semi-arides. UNESCO, Paris, 15.

[5] Subyani, A.M. (2004) Geostatistical Study of Annual and Seasonal Mean Rainfall Patterns in Southwest Saudi Arabia. Hydrological Sciences Journal, 49, 803-817. https://doi.org/10.1623/hysj.49.5.803.55137

[6] Hasanean, H. and Almazroui, M. (2015) Rainfall: Features and Variations over Saudi Arabia, a Review. Climate, 3, 578-626. https://doi.org/10.3390/cli3030578

[7] Dyson, L.L. (2009) Heavy Daily-Rainfall Characteristics over the Gauteng Province. Water $S A$, 35, 627-638. https://doi.org/10.4314/wsa.v35i5.49188 
[8] Khan, R. (2013) Flood as a Disaster in the Middle East Region. International Journal of Scientific Engineering and Research, 1, 121-127.

[9] https://www.niwa.co.nz/natural-hazards/extreme-weather-heavy-rainfall

[10] Youssef, A. M., Sefry, A., Pradhan, B. and Abou Elfadel, E. (2016) Analysis on Causes of Flash Flood in Jeddah City (Kingdom of Saudi Arabia) of 2009 and 2011 using Multi-Sensor Data and GIS. Geomatics Natural Hazards and Risks, 7, 1018-1042.

[11] Daoudi, M. (2014) Risque d'inondations et vulnérabilité de la ville de Jeddah, Arabie Saoudite. Flood Risk and Vulnerability of the City of Jeddah, Saudi Arabie. GEO-ECO-TROP, 38, 259- 270.

[12] Meschinet de Richemond, N. (2003) Statut et perception des catastrophes passées: Vers une histoire géopolitique des risques naturels. In: Moriniaux, V., Ed., Les Risques, éditions du Temps, Nantes, 138-156.

[13] United Nations (2016) World Population Prospects. https://esa.un.org/unpd/wpp/

[14] UNESCO (1964) La recherche scientifique en vue de développement de l'Arabie Saoudite. $47 \mathrm{p}$.

[15] Salam, A.A. (2013) Population and Household Census, Kingdom of Saudi Arabia 2010: Facts and Figures. International Journal of Humanities and Social Science, 3 , 258-263.

[16] Abou-Korin, A. and Saad Al-Shihri, F. (2015) Rapid Urbanization and Sustainability in Saudi Arabia: The Case of Dammam Metropolitan Area. Journal of Sustainable Development, 8, 25-65.

[17] Brunet, R., Ferras, R. and Théry, H. (2005) Les Mots de la Géographie. La Documentation française, France, 518.

[18] Crichton, D. (1999) The Risk Triangle. In: Ingleton, J., Ed., Natural Disaster Management, Tudor Rose, 102-103.

[19] Qari, H.A., et al. (2014) Flood Management in Highly Developed Areas: Problems and Proposed Solutions. Journal of American Science, 10, 6-15.

[20] Al Saud, M. (2015) Flood Control Management for the City and Surroundings of Jeddah, Saudi Arabia. The Springer Natural Hazards, Springer Science + Business Media, Dordrecht, 177 p.

[21] http://www.alayam.com/alayam/last-page/443107

[22] http://www.al-madina.com/article/122723

[23] https://www.theguardian.com/commentisfree/2009/dec/03/jeddah-floods-sewage-al -saud

[24] http://www.arabnews.com/editorial-jeddah-flooding-be-thing-past 